\title{
Kokemäenjoki River Delta, Western Finland - Natural Treasury in an Exceptionally Rapidly Changing Aquatic Environment
}

\author{
Kai Aulio* \\ Department of Biology, University of Turku, FI-20014 Turun yliopisto, Finland \\ Present address: Lankakatu 3 D 16, FI-20660 Littoinen, Finland \\ *E-mail address: kai.aulio@gmail.com
}

\begin{abstract}
The catchment of the River Kokemäenjoki covers ca. 27100 square kilometers in western Finland, and the the length of the river is ca $120 \mathrm{~km}$. The river discharges into the Bothnian Bay, the northern section of the Baltic Sea. The delta is changing and prograding towards the sea exceptionally rapidly. The pace of the growth of the deltaic formations, a $\mathrm{s}$ well as the major zones of the macrophytive vegetation is nowadays some 30-40 meters a year. This makes the delta the most rapidly changing aquatic and littoral ecosystem in the Northern Europe.

The Kokemäenjoki River delta is often characterized as a biological hotspot, and major sections of the estuary are included in several leading international nature conservation programmes, i.e. The Natura 2000 network of the European Union, the intergovernmental The Ramsar Convention on Wetlands, as well as in the IBA, Important Bird Area programme established by the BildLife International organization.

The diversities of both flora and fauna are very high - at least as regards of the northern location of the estuary. In the Kokemäenjoki River ca. 420 taxa of flowering plants (Spermatophyta) are permanently found (i.e. about a third of the ca. 1200 flowering plants permanently growing in Finland). Of the pteridophytes (Pteridophyta), there are 17 out of the 57 species of the Finnish taxa growing at the delta. Of the stoneworts (Chrarophyta) the delta is home of 9 species of the 21 taxa found in Finland.

The number of bird species breeding in the area is ca. 110, and the total number of bird taxa living and resting during the migration periods amounts to 220 species (i.e. nearly the whole range of the 248 bird species of the permanent Finnish bird taxa). Of the invertebrates, the species composition of dragonflies (Odonata) is best known. There are 25 species of the 55 dragonfly taxa found in
\end{abstract} Finland.

Of the plant species occupying the delta, 5 species of flowering plants and one species of stoneworts are classified as endangered, fulfilling the red list criteria established by the International Union for Conservation of Nature (IUCN). Of the bird species of the estuary, 31 species are included in the Red List of endangered species.

The present paper summarizes the data presented in various reports, mainly in Finnish, and majority of them in hardly accessible depositories.

Keywords: Kokemäenjoki River delta; Pihlavanlahti Bay; nature conservation; biodiversity 


\section{PIHLAVANLAHTI BAY - CONSTANTLY CHANGING ESTUARY}

The Kokemäenjoki River estuary - Pihlavanlahti Bay - in western Finland (Northern Europe; 61 $34^{\circ} \mathrm{N}, 21^{\circ} 40^{\prime} \mathrm{E}$; Figure 1) is brackish water-freshwater ecosystem, where the deposition of river-borne sediments, the land upheaval, and the accumulation of autochthonous, locally produced plant material is more rapid than in any other river delta in the Northern Europe [1],[2]. The estuary, discharging into the Bothnian Bay, the northern section of the Baltic Sea, is a shallow sedimentation basin, which is nearly thoroughly covered with rich and exceptionally productive macrophytic vegetation [3],[4]. The delta in the estuary is proceeding very rapidly due to the deposition of sediments carried by the River Kokemäenjoki, the accumulation of autochthonous organic (plant) matter, and due to land uplift, typical to the shores of the Baltic Sea. At present, the extent of the land uplift in the area is 5.5 millimeters a year. The deltaic deposits (formation of new sandbanks and islands), as well as the distribution of the vegetation zones are today moving towards the sea at an average speed of 30-40 meters a year [5], [6].

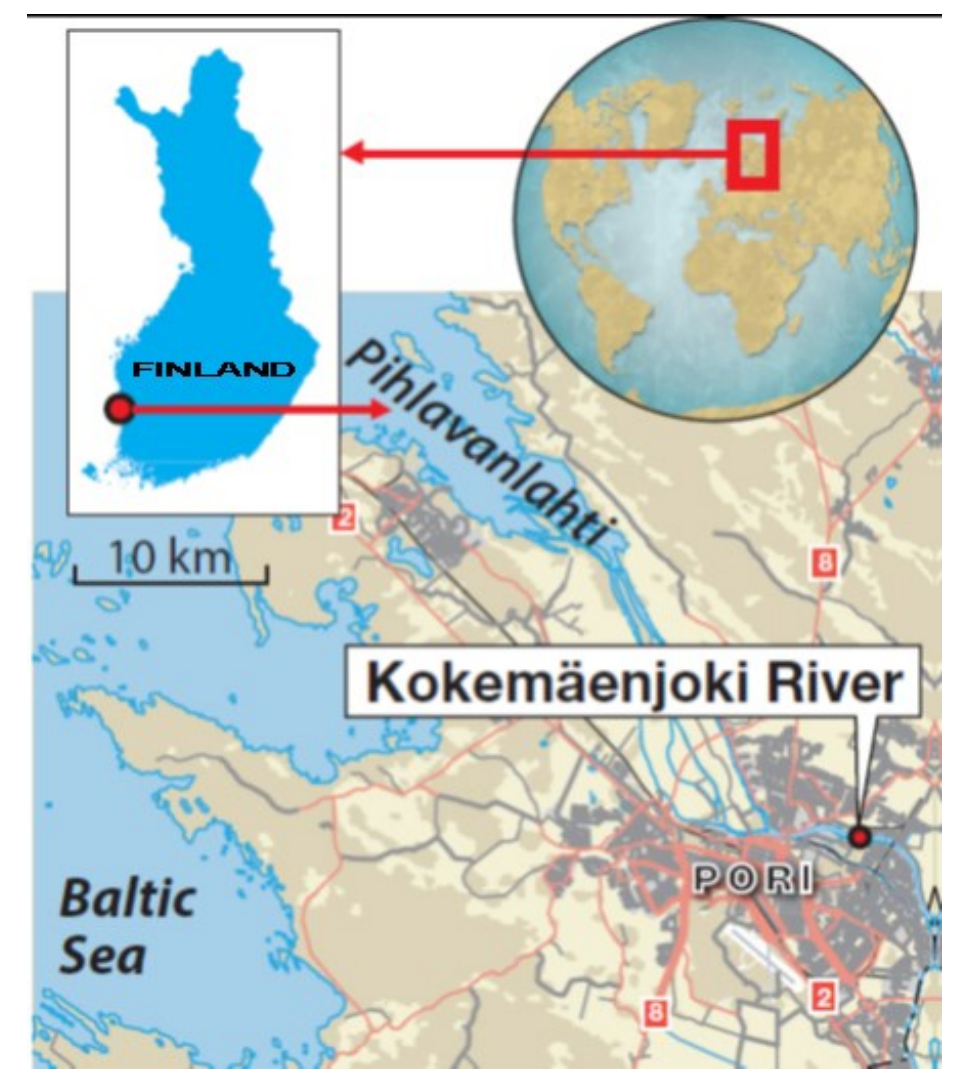

Figure 1. Location of the study area.

The decrease of water depth caused by the deposition of river-borne sediments can account as much as 30-33 millimeters a year. The maximum sedimentation takes place at the distance of about 500 meters from the discharge point, and the deposition zone reaches some two kilometers towards the sea [6], [7]. The average amount of sedimentation-borne decrease in the water depth is 6-7 millimeters a year. This equals the amount of the continuous land 
upheaval in the area. The total amount of sediments that the River Kokemäenjoki carries into the estuary is some 100000 cubic meters a year [7].

The relative land upheaval on the Baltic Sea coast - i.e. the lift of the bedrock after the subsidence caused by the latest ice age - at Mäntyluoto, adjacent to the Pihlavanlahti Bay accounts for $6.07 \pm 0.44$ millimeters a year. The absolute water rise - when the global sea level rise and the tiny tidal effects are taken into account - accounts for $7.57 \pm 0.67$ millimeters a year [8].

\section{FRESH WATER, HIGHLY EUTROPHICATED BY ANTHROPOGENIC DISCHARGES}

The water of the estuary is essentially fresh water carried by the River Kokemäenjoki. The water of the river and of the estuary were highly polluted and eutrophicated during past decades, but due to effective water purification and conservation efforts, the aquatic environment of the area is now considered clean and healthy [9]. The penetration of sea water into the estuary is restricted by road embankments, and also naturally by many small islands. The water of the adjacent, northern reach of the Baltic Sea is brackish water with a salt concentration of only $0.1-0.5 \%$.

The surface area of the Pihlavanlahti Bay is about 38 square kilometers. The mean water depth of the estuary is about three meters. Due to the shallow waters, there are no vertical stratifications in temperature or salt concentrations.

Daily variations in the water level at the Pihlavanlahti Bay are minor, usually less than $20 \mathrm{~cm}$. Changes are determined by the sea level fluctuations, caused by the wind. More than $50 \%$ of the daily variations in the water level are less than $10 \mathrm{~cm}$, and only in $4 \%$ the amplitude of daily fluctuations is wider than $30 \mathrm{~cm}$ [10]. Tidal activity is negligible in these coastal waters of the Northern Baltic Sea. In the processes of sedimentation and decrease of water depth, the role of the rigorous aquatic and littoral vegetation is of paramount importance. The estuary is shallow, and due to the eutrophic waters the Pihlavanlahti Bay is thoroughly covered with macrophytic vegetation. The rapid changes in the environmental conditions result in exceptional variation in the communities and local distribution of plants.

On the basis of water quality, the Pihlavanlahti Bay is eutrophic. The River Kokemäenjoki is one of the most impressive examples of successful water management and purification processes in Finland [9]. Due to industrial and municipal waste waters, the physico-chemical properties of the water in the Pihlavanlahti Bay were previously classified as heavily polluted [11]. Due to the nutrient loads carried to the estuary by the River Kokemäenjoki were high [12], and eutrophication of the whole ecosystem was more severe than in most other water courses in the Northern Europe. On the basis of primary production by phytoplankton, the area was classified as highly eutrophicated [13].

The development of waste water purification and huge investments in management, the water quality started gradually recover. In the late 1980's the anthropogenic nutrient burden enhanced the primary production by 10-40 milligrams of carbon assimilated per a cubic meter of water [6]. 


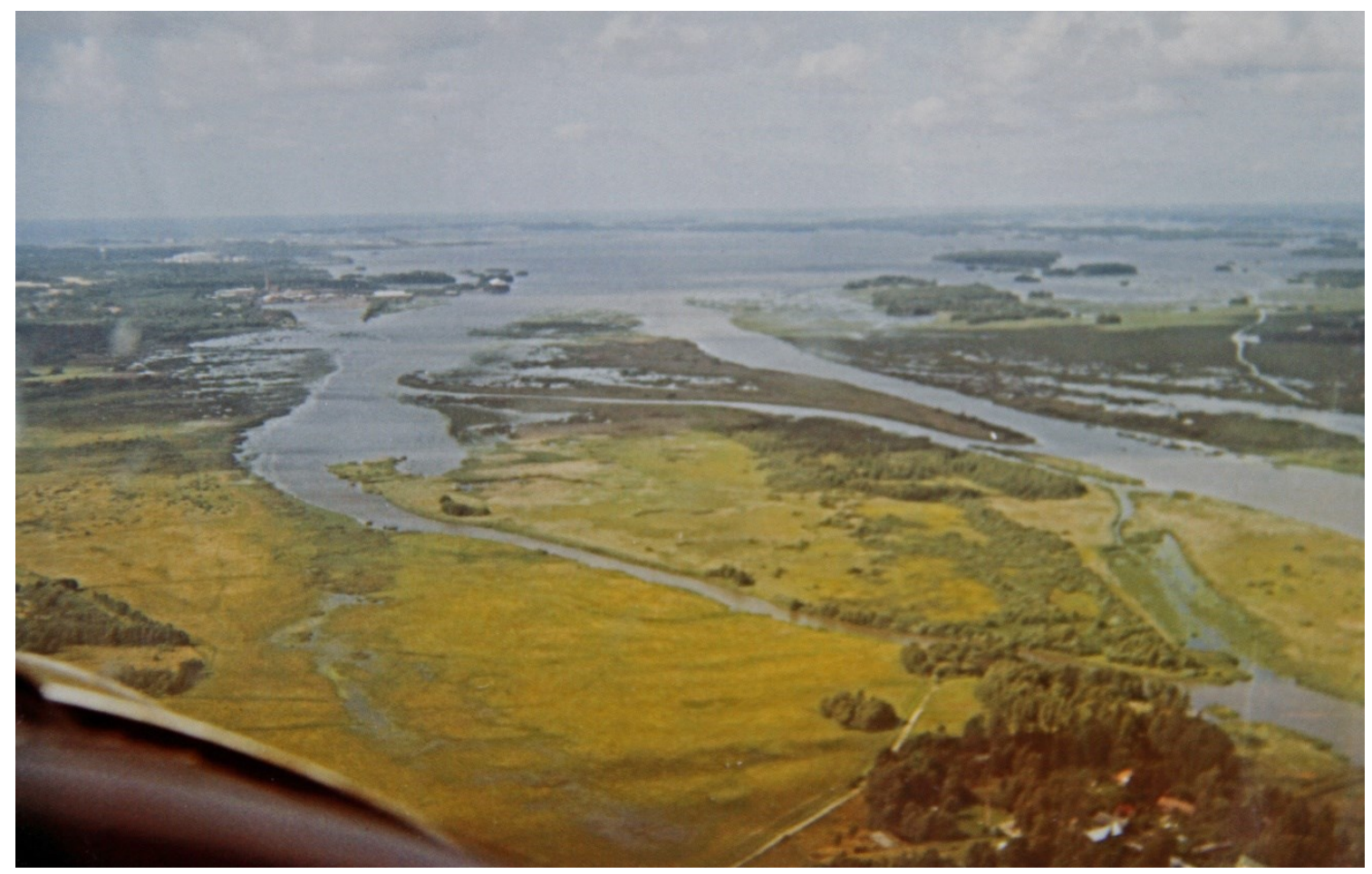

Figure 2. Aerial view of the Pihlavanlahti Bay in mid 1970's (Photo Kai Aulio).

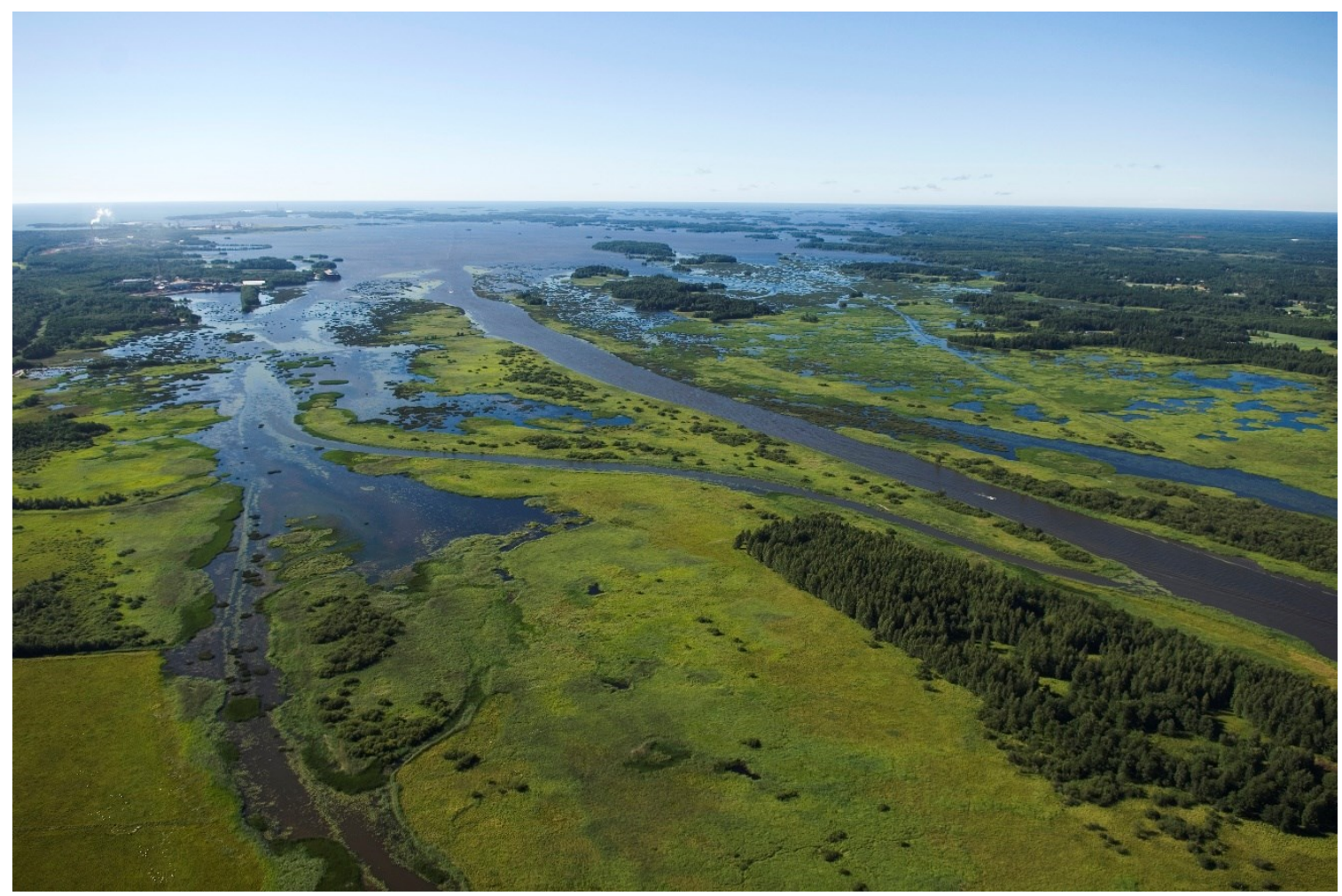

Figure 3. Aerial view of the Pihlavanlahti Bay, July 2007 (Photo Lentokuva Vallas Oy). 
Nowadays, due to active management efforts and investments, the River Kokemäenjoki and the Pihlavanlahti Bay have recovered from the state of negligence and the past generations' sins [9]. But, in spite of remarkable enhancements, the water of the Pihlavanlahti Bay is still eutrophicated (Table 1; [14]. When evaluated by water quality criteria and multipurpose use possibilities, the Kokemäenjoki River estuary is today in poor or tolerable condition [15].

Table 1. The average water quality parameters in the Kokemenjoki River delta, the annual average values for 2008-2010. Source: ref. [14].

\begin{tabular}{|c|c|}
\hline Parameter & $\begin{array}{c}\text { Value } \\
\text { (annual average) }\end{array}$ \\
\hline Oxygen, $\mathrm{O}_{2}(\mathrm{mg})$ & 9.7 \\
\hline $\begin{array}{c}\text { Oxygen saturation } \\
(\%)\end{array}$ & 87 \\
\hline $\begin{array}{c}\text { Sameus (FNU) } \\
(\mathrm{mS} / \mathrm{m})\end{array}$ & 9.8 \\
\hline $\begin{array}{c}\text { Conductivity } \\
\mathrm{pH}\end{array}$ & 70 \\
\hline $\begin{array}{c}\text { Colour }(\mathrm{mg} \mathrm{Pt} / \mathrm{l}) \\
\text { COD }\end{array}$ & 70 \\
\hline Total $\mathrm{Ng} / \mathrm{l}(\mu \mathrm{g} / \mathrm{l})$ & 9.5 \\
\hline Total $\mathrm{P}(\mu \mathrm{g} / \mathrm{l})$ & 30 \\
\hline Fe $(\mu \mathrm{g} / \mathrm{l})$ & 488 \\
\hline $\begin{array}{c}\text { Fecal coliforms } \\
(\text { number/100 ml })\end{array}$ & 139 \\
\hline
\end{tabular}

The Kokemäenjoki River and the Pihlavanlahti Bay were serious examples of mercury pollution until 1980's [16]. Today the levels of $\mathrm{Hg}$ are at or near natural state in the waters and the surface sediments, but in the deeper sediment layers the "the old sins" are still a serious risk. In the official water quality follow-up study of the Kokemäenjoki, the mercury concentration of the river water upsteream of the delta was $<0.003 \mu \mathrm{g} / 1$ [14].

The improvement of the water quality is best evidenced by the fact that the mercury levels even in the biggest and oldest pike and other predatory fish - previously in total prohibition - are now suitable to be used for human consumption.

The buried deposits of toxic metals can, however, become available to the biota, when the deposits are dredged for the deepening of channels and waterways or for the flood management projects [6].

The prevailing wind direction in the Pihlavanlahti Bay - affecting the water directions and strengths of the water currents - are southerly. The common share of SW, S, and SE 
winds averages $46 \%$, and accordingly, the share of NW, N, and NE winds is $34 \%$, on average. The median speed of the winds in the area is 4.1 meters a second [17]. The changes in water currents due to winds, as well as road constructions across the distal section of the edtuary are well known [18].

\section{GEOLOGY: COMBINATION OF OLD AND NEW}

The geological features of the Pihlavanlahti bay and the surrounding areas are consisted of two main bedrock types. The northern/northeastern part of the are the bedrock consists of granitic rocks, i.e. granodiorite and quarz diorite and granite veins in migmatitic gneiss, whereas the southern/southwestern half of the estuary is formed on (geologically younger) jothnian sandstone [19].

In the landscape, the islands and sandbanks and bars represent two types, according to the geological base. On the granitic bedrock, the islands have a solid rock core, and the soils are moraine, deposited during the regressing phase of the latest ice age. On the SW part of the presently growing delta, the islands and bars are created via deposition of the river-borne sediments [6].

Sedimentation load carried by the River Kokemäenjoki and deposited at the Pihlavanlahti Bay is exceptionally high, as compared to average river waters in Finland and other Nordic countries [20]. As a consequence, the sedimentation process lead to very quick shallowing of the estuary, and the creation of new sand banks and islands. The pace of sedimentation has been studied during several decades, and the sequential trends in the sedimentation and silt-up processes are well-known.

\subsection{Transitions of the Coastline Are Well-known}

Historically, the movement of the delta towards the sea has varied considerable, basically due to the local differences in the "pre-sedimentation" conditions. The rough estimation for the speed of the growth of the Kokemäenjoki River delta in the period 15581724 was 14 meters a year, and subsequently in the period 1724-1836 the enhancement of the delta was some 35 meters a year, on the average [6].

The variations have been remarkable. The exceeding of the delta was at the quickest during the period 1836-1859. During this period the progress was some 60 meters a year, on the average. But in the succeeding decades, between the years 1859 and 1905, the delta grew at the pace of $27 \mathrm{~m} /$ year, and during the period 1905-1947 the growth and enhancement of the delta were at their maximum, with an average pace of some 78 meters a year [7].

Based on the published research, the average speed of the movement of the delta towards the sea was some 36 meters a year in the period 1836-1897, and some 36 meters per year during 1897-2001. On the other hand, estimated from the most previous national cartography, the delta proceeded at the average speed of some $40 \mathrm{~m}$ per year during 1958 1982, and at the pace of some 30 meters a year in the period 1981-2001. The present pace of delta formation and prograding towards the sea by 30-40 meters a year [6].

Due to massive flood prevention and management projects, the channel of the Kokemäenjoki River is annually dredged, and flood barriers bordering the channel prevent the spread of waters and the sedimentation of river-borne sediments. As a result, the sedimentation has enhanced, and accordingly, the pace of the prograding of the delta towards the sea has accelerated in recent years/decades. The future of the Pihlavanlahti Bay - and also 
the conservation values of the Natura 2000 reserve - depend strongly of the decisions made in the flood prevention and regulation works.

\section{EXCEPTIONAL BIODIVERSITY HOTSPOT IN THE NORTH}

\subsection{Part of Several National and International Conservation Programmes}

Biologically the estuary is very rich, and from 2004 the site has been part of the Natura 2000 conservation network of the European Union (= FI020079 Kokemäenjokisuisto), on the basis of SCI (Sites of Community Importance) -area determined by the EU's Nature Directive (92/43/ETY) and also as a SPA (Special Protection Area) -area on the basis of the Bird Directive (79/409/ETY) of the European Union. The Pihlavanlahti Nature 2000 conservation area covers a total of 2885 hectares consisting of aquatic, wetland and island habitats.

The conservation area is actively managed by the national environmental authorities, i.e. The Centre for Economic Development, Transport and the Environment for Southwest Finland [21]. The estuary is also part of the intergovernmental Ramsar Convention on Wetlands network of valuable bird sanctuaries. The values of the Pihlavanlahti Bay for birds in emphasized by the inclusion in the IBA (Important Bird Area) network, established by the BirdLife International organization. In addition, part of the delta belongs to The National Urban Parks -network, summarizing both natural and cultural values.

\subsection{Vegetation Follow-up Studies for More Than 100 Years}

The biota of the study area is exceptionally rich as compared to typical natural habitats in Northern Europe. The number of vascular plant taxa growing at the Pihlavanlahti Bay is about 440. The flora includes several endangered. Table 2 lists typical and representative taxa of purely aquatic plant species, as well as plants from moist littoral habitats in the Kokemäenjoki River delta.

Studies of the species composition of aquatic and littoral vegetation of the Kokemäenjoki River estuary were published as early as in the beginning of the $20^{\text {th }}$ century by Ernst Häyrén [22]. Since then, several follow-up studies and surveyings/mappings have been published. Remarkable changes due to the natural development of the delta, as well due to drastic anthropogenic influences (e.g. pollution, construction, boat traffic, dredging) were recorded by Ihantola [23],[24], Kalinainen [25], Lampolahti [26], [27], Paakkinen [28], Ahlman [29] and Suominen [30].

Of the aquatic macrophytic plants, the most valuable species in the Kokemäenjoki River delta is Persicaria foliosa (H.Lindb.) Kitag. (Polygonaceae), a small littoral plant of the wide genus of Smartweeds. P. foliosa is especially important here because the taxa was originally described in Finland, and Finland carries the main responsibility of the conservation of the species.

Besides being conserved by the national law, P. foliosa is included in the Nature directive (Appendices II and IV) of the European Union. In the official classification [31] The 2010 Red List of Finnish Species - Persicaria foliosa is in the Endangered category (EN), due to the tiny area of population and the small and variable/labile number of mature individuals. Overgrowth, caused by eutrophication and dredging are the main causes of threat for $P$. foliosa. The tiny and labile population size is the main threatening factor for $P$. foliosa in the Pihlavanlahti Bay, as well as in other locations of this species. 
Table 2. List of aquatic and littoral macrophytes of the Kokemäenjoki River delta. Source: refs [23-30]. (Original publications in Finnish).

\begin{tabular}{|c|c|c|}
\hline Family & Species & $\begin{array}{c}\text { Life } \\
\text { form(s) }\end{array}$ \\
\hline Isoetaceae & Isoetes echinospora, Isoetes lacustris & I \\
\hline Equisetaceae & Equisetum fluviatile, E. x litorale & $\mathrm{E}$ \\
\hline Nymphaeaceae & Nymphaea alba ssp. candida, Nuphar lutea & $\mathrm{N}$ \\
\hline Ceratophyllaceae & Ceratophyllum demersum & $\mathrm{C}$ \\
\hline Ranunculaceae & $\begin{array}{c}\text { Caltha palustris, Ranunculus flammula, } R \text {. peltatus ssp. } \\
\text { peltatus, } R \text {. reptans, } R \text {. sceleratus }\end{array}$ & $\mathrm{H}$ \\
\hline Caryophyllaceae & Spergularia salina & $\mathrm{H}$ \\
\hline Chenopodiaceae & Salicornia europaea & $\mathrm{H}$ \\
\hline Polygonaceae & $\begin{array}{c}\text { Rumex crispus, } R \text {. hydrolapathum, Persicaria amphibia, } P . \\
\text { foliosa, } P \text {. hydropiper, } P \text {. lapathifolia ssp. lapathifolia, } P . \\
\text { minor }\end{array}$ & $\mathrm{N}, \mathrm{H}$ \\
\hline Elatinaceae & Elatine hydropiper, E. orthosperma, E. triandra & E, I \\
\hline Brassicaceae & $\begin{array}{c}\text { Barbarea stricta, Cardamine amara, Erysimum strictum, } \\
\text { Subularia aquatica, Rorippa palustris }\end{array}$ & $\mathrm{H}$ \\
\hline Primulaceae & Glaux maritima, Lysimachia thyrsiflora, L. vulgaris & $\mathrm{H}$ \\
\hline Crassulaceae & Tillea aquatica & $\mathrm{I}, \mathrm{E}$ \\
\hline Rosaceae & Comarum palustre & $\mathrm{H}$ \\
\hline Fabaceae & Lathyrus palustris & $\mathrm{H}$ \\
\hline Lythraceae & Lythrum salicaria & $\mathrm{H}$ \\
\hline Haloragaceae & Myriophyllum alterniflorum, $M$. spicatum, $M$. verticillatum & $\mathrm{E}$ \\
\hline Apiaceae & Cicuta virosa, Oenanthe aquatica, Peucedanum palustre & $\mathrm{H}$ \\
\hline Rubiaceae & Galium palustre & $\mathrm{H}$ \\
\hline Menyanthaceae & Menyanthes trifoliata & $\mathrm{H}$ \\
\hline Boraginaceae & Myosotis laxa & $\mathrm{H}$ \\
\hline Lamiaceae & $\begin{array}{c}\text { Lycopus europaeus, Mentha arvensis, Scutellaria } \\
\text { galericulata }\end{array}$ & $\mathrm{H}$ \\
\hline Callitrichaceae & Callitriche hermaphroditica, C. cophocarpa, C. palustris & $\mathrm{E}$ \\
\hline Scrophulariaceae & Limosella aquatica, Veronica longifolia & $\mathrm{I}, \mathrm{H}$ \\
\hline Lentibulariaceae & $\begin{array}{c}\text { Utriclaria australis, } U . \text { intermedia, U. minor, } U . \\
\text { ochroleuca, U. vulgaris }\end{array}$ & $\mathrm{C}$ \\
\hline Hippuridaceae & Hippuris vulgaris & $\mathrm{H}$ \\
\hline Asteraceae & Cirsium palustre & $\mathrm{H}$ \\
\hline Butomaceae & Butomus umbellatus & $\mathrm{H}$ \\
\hline Alismataceae & Alisma plantago-aquatica, Sagittaria sagittifolia & $\mathrm{H}$ \\
\hline Hydrocharitaceae & Elodea canadensis, Hydrocharis morsus-ranae & E, $N$ \\
\hline Juncaginaceae & Triglochin maritime, $T$. palustris & $\mathrm{I}, \mathrm{H}$ \\
\hline Potamogetonaceae & $\begin{array}{l}\text { Potamogeton perfoliatus, } P \text {. pectinatus, } P \text {. gramineus, } P \text {. } \\
\text { friesii, } P \text {. berchtoldii, } P \text {. alpinus, } P \text {. obtisifolius, } P \text {. natans }\end{array}$ & $\mathrm{E}, \mathrm{N}$ \\
\hline Zannichelliaceae & Zannichellia palustris & $\mathrm{I}$ \\
\hline Iridaceae & Iris pseudacorus & $\mathrm{H}$ \\
\hline
\end{tabular}




\begin{tabular}{|c|c|c|}
\hline Juncaceae & $\begin{array}{c}\text { Juncus alpinoarticulatus, J. alpinoarticulatus ssp. } \\
\text { alpinoarticulatus J. alpinoarticulatus ssp. nodulosus, J. } \\
\text { articulates, J.bufonius, J. bulbosus, J. conglomeraus, J. } \\
\text { effusus, J. filiformis, J. gerardii }\end{array}$ & $\mathrm{N}, \mathrm{H}$ \\
\hline Cyperaceae & $\begin{array}{c}\text { Eleocharis acicularis, E. mamillata, E. palustris, E. } \\
\text { uniglumis, Carex pallescens, C. diandra, C. vesicaria, C. } \\
\text { mackenziei, C. elongate, C. rostrate, C. pseudocyperus, C. } \\
\text { aquatilis, C. acuta, Schoenoplectus maritimus, } S . \\
\text { tabernaemontani, Scirpus sylvaticus, Eriophorum } \\
\text { angustifolium, E. vaginatum }\end{array}$ & $\mathrm{I}, \mathrm{H}$ \\
\hline Poaceae & $\begin{array}{c}\text { Alopecurus aequalis, Glyceria fluitans, G. maxima, } \\
\text { Phalaris arundinaceae, Phragmites australis, Poa } \\
\text { palustris, Puccinellia capillaris, Scholochloa festucaceae }\end{array}$ & $\mathrm{H}$ \\
\hline Sparganiaceae & $\begin{array}{c}\text { Sparganium erectum ssp. erectum, S. erectum ssp. } \\
\text { microcarpum, S. glomeratum, S. emersum, S. gramineum, } \\
\text { S. natans }\end{array}$ & $\mathrm{E}, \mathrm{N}, \mathrm{H}$ \\
\hline Typhaceae & $\begin{array}{c}\text { Typha angustifolia, } \text { T. latifolia, } \text { T. } x \text { glauca }(=T . \\
\text { angustifolia } x \text { T. latifolia) }\end{array}$ & $\mathrm{H}$ \\
\hline Araceae & Acorus calamus, Calla palustris & $\mathrm{H}$ \\
\hline Lemnaceae & Lemna minor, L. trisulca, Spirodela polyrhiza & $\mathrm{L}, \mathrm{C}$ \\
\hline
\end{tabular}

Life forms: $\mathrm{L}=$ lemnids (free-floating), $\mathrm{C}=$ ceratophyllids (submerged, non-rooted), $\mathrm{E}$ = elodeids (submerged, rooted), $\mathrm{I}=$ isoetids (rooted rosette plants), $\mathrm{N}=$ nymphaeids (floatingleaved, rooted), $\mathrm{H}=$ helophytes (rooted, with most of leaves and stems above water surface).

The Yellow Spring bedstraw (known also as Lady's Bedstraw) (Galium verum L.) (Rubiaceae) is classified as vulnerable (VU) in Finland. In the Kokemäenjoki River delta $G$. verum is rare, occupying some dry shore meadows. Causes of threat of this species are overgrowth of the open meadow habitats, and as a new threat, the hybridization with a close relative and an introduced (alien) species Galium album Mill.

Overgrowth by the tall reedswamps (especially Phragmites australis (Cav.) Trin ex Steudel) is the main threatening factor for the small littoral isoetid plant Water pygmyweed (known also as Common pygmyweed) Crassula aquatica (L.) Schönl. (Crassulaceae). In the official classification, C. aquatica is classified as vulnerable (VU), due to fragmented and declining locations of occurrence and the small number of mature individuals. In the Kokemäenjoki River delta, C. aquatica is met only in limited local shore alluvia. Overgrowth, caused by eutrophication and dredging are the main factors threatening the species. During the recent decade, the conservation status of $C$. aquatica was strengthened from the category Near Threatened (NT) into the Endangered category (EN).

Of the helophytic aquatic taxa, the Water dropwort Oenanthe aquatica (L.) Poir. (Apiaceae) occupies eutrophic habitats, and the plant is found only sporadically as small and fragmented populations. In Finland, O. aquatica is classifies as Near Threatened, mainly due to anthropogenic factors such as construction of waterways, dredging, and overgrowth by stronger reedswamp vegetation due to eutrophication of the habitats.

There are 9 species of pondweeds (Potamogeton spp.) occupying permanently the Pihlavanlahti Bay. Of there, the Flat-stalked pondweed (known also as Fries' pondweed) (Potamogeton friesii Rupr.) is classified as Near Threatened (NT) in the 2010 Red List of Finnish Species [31]. Eutrophication and other chemical pollution, as well as dredging and 
other construction of waterways are the main threatening factors for the rare submerged plants. The conservation status has remained the same as in 2000.

The Common eelgrass (known also as the Seawrack), Zostera marina L. is a genuine marine plant, and in the Kokemäenjoki River delta the taxa is found only in the distal end of the estuary. Here the plants is at its outermost northern limit of the geographic area of occurrence, and as such the occurrences are rare, restricted and with only small number of individuals. Eutrophication of the coastal waters, caused by anthropogenic discharges of nutrients, is the main cause of threat for Z. marina.

The moss flora occupying the aquatic and moist littoral habitats shows a declining trend, although the reasons for the changes are unknown. The most probable explanation for the decline is enhanced competition by the tall and strong flowering plants. In the recent mapping of the vegetation of the aquatic and moist littoral habitats in the Kokemäenjoki River delta, Ahlman [29] listed 12 species of Bryophyta. Common water moss (Fontinalis antipyretica Hedw.) is the dominant species in the aquatic Brophyta in the estuary. Other typical species are Heart-leaved Spear-moss (Calliergon cordifolium (Hedw.) Kindb.) and Calliergon moss (C. megalophyllum Mikut.) and Drepanocladus sordidus (Müll. Hal.) Hedenäs.

The free-floating liverworts (Hepaticae) Ricciocarpos natans (L.) Corda and Riccia fluitans L. are indicators of eutrophication, even anthropogenic water pollution. On the other and, the two spacies of Warnstorfia fluitans (Hedw.) Loeske and W. trichophylla (Warnst) Tuom. \& T. Kop. occupy typically clear and oligotropgic waters. In addition, four species of Sphagnum mosses occupying moist littoral microhabitats were listed [29].

Of the 21 species of stoneworts (Characeae) known from Finland, 9 species are found in the Kokemäenjoki River delta [23],[26],[29]. Of these one species, Braun's Stonewort (Chara braunii C.C. Gmel.) is classified as Vulnerable (VU). Eutrophication and overgrowth of open aquatic habitats, together with dredging are the main threatening factors for stoneworts.

\subsection{Vegetation Zones Spread 30 Meters a Year Towards the Sea}

In addition to the remarkable species richness, rapid and wide changes in the zonation of the dominant aquatic and littoral vegetation characterize the Kokemäenjoki River delta. The field work by Säntti [32] gives a picture of the major vegetation communities and zones in the mid-1950's. The follow-up study in mid-1970's by Aulio [3] showed that the major zones move characteristically according to the formation of new deltaic deposits and the shallowing of the water depth.

The pace of the movement of the vegetation reflects the speed of the sedimentation progress. The major zones are moving some 30 meters a year towards the sea. During the recent three decades, the vegetated area of the delta has spread about one kilometer towards the sea (Figures 2 and 3).

The complexity in the water depths is mixing up the regular zonation, and changes in the water quality also affect the flora and the major vegetation zones. In the recent decades, the most characteristic feature in the major zonation of macrophytic vegetation in the Kokemäenjoki River delta is the drastic decline of Equisetum fluviatile L., the remarkable dominance of Schoenoplectus lacustris, and the marked increase in the coverage of Typha angustifolia L. and Acorus calamus L. [29],[30].

In the landscape, the tallest and most widely helophytic macrophyte is - and has been for the whole follow-up period - the common reed Phragmites australis. (Figure 4). The growth and production ecology, and the ecologically appropriate changes/strategies in those 
characteristics due to the successional development of the delta are presented in several studies [3],[4],[33],[34],[35].

The production capacity of Phragmites australis in the Kokemäenjoki River delta is very high, although the annual production of aboveground biomass up to over $5 \mathrm{~kg}$ (dry weight) per square meter is only a small-scale curiosity [36].

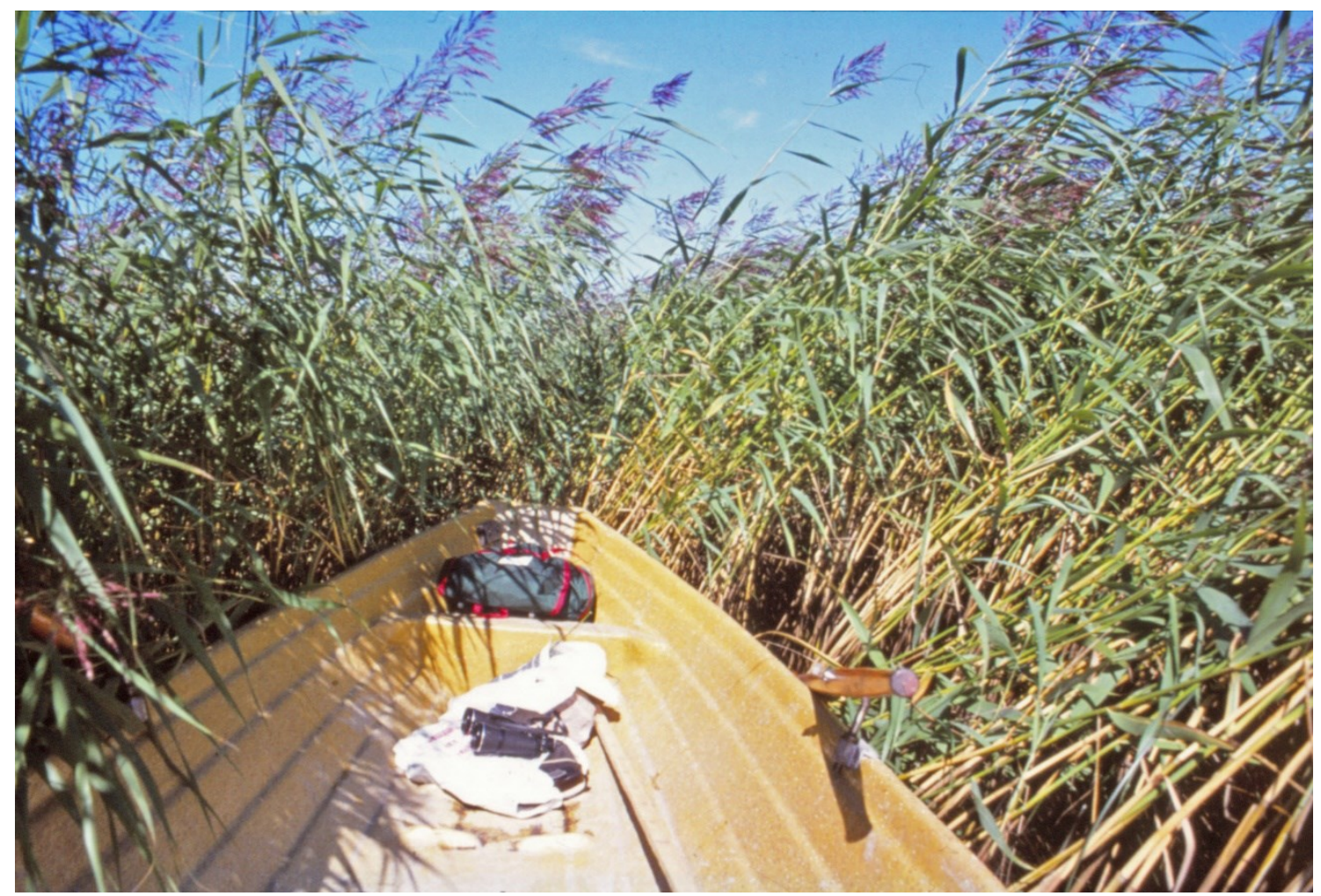

Figure 4. The stands of helophytic macrophytes are impenetrable. The common reed Phragmites australis is the dominant species in the proximal and middle sections of the Kokemäenjoki River delta

(Photo Kai Aulio).

In addition, examples of the aquatic and littoral flora of the Kokemäenjoki River delta have proved to be valuable indicator organisms for monitoring of aquatic pollution. The estuary is an ideal location for such investigations because the area receives a very diverse loads of metals, and the rich flora occupies aquatic habitats that are practically uniform. So any differences in the metal contents the plants accumulate can be pointed as species-specific characteristics.

Promising indicator taxa were found both in the comparison between the life forms (helophytes, floating-leaved, submerged) [37], as well as in the comparison within the Pondweed genus (Potamogeton spp.) [38].

\subsection{Birdlife Paradise, With Nearly All Finnish Species Represented}

The Kokemäenjoki River delta, together with the adjacent sea shores by the Bothnian Sea is characterized as a birdlife paradise, and for reason. There are about 110 bird species 
permanently living at the Pihlavanlahti Bay area, and the estuary is one of the most important resting and molting areas during migrations.

The number of bird species met annually at the Pihlavanlahti Bay area reaches about 220 species (Table 3). The Kokemäenjoki River delta is an internationally important area for both local and migratory birds - determined with every criteria used in the biodiversity evaluations [39], [40].

Table 3. Endangered bird species in the Kokemäenjoki River delta. Taxa included in the National Red List 2010. Source: refs. [39],[40] [41],[42].

\begin{tabular}{|c|c|c|}
\hline $\begin{array}{c}\text { Common Name } \\
\end{array}$ & Scientific Name & Family \\
\hline \multicolumn{3}{|c|}{ Critically Endangered (CR) - 3} \\
\hline Greater Spotted Eagle & Clanga clanga Pallas & Accipitridae \\
\hline Southern Dunlin & Calidris alpina schinzii $\mathrm{L}$. & Scolopacidae \\
\hline Yellow-breasted Bunting & Emberiza aureola Pallas & Emberizidae \\
\hline \multicolumn{3}{|l|}{ Endangered (EN) - 5} \\
\hline Montagu's Harrier & Circus pygargus L. & Accipitridae \\
\hline Black-tailed Godwit & Limosa limosa L. & Scolopacidae \\
\hline Ruff & Philomachus pugnax L. & Scolopacidae \\
\hline Little Tern & Sterna albifrons Pallas & Laridae \\
\hline Ortolan Bunting & Emberiza hortulana L. & Emberizidae \\
\hline \multicolumn{3}{|l|}{ Vulnerable (VU) - 11} \\
\hline Horned Grebe & Podiceps auritus L. & Podicipedidae \\
\hline Northern Pintail & Anas acuta $\mathrm{L}$. & Anatidae \\
\hline Garganey & $\begin{array}{c}\text { Garganey querquedula L. }= \\
\text { Anas querquedula L. }\end{array}$ & Anatidae \\
\hline Common Pochard & Aythua ferina $\mathrm{L}$. & Anatidae \\
\hline Tufted Duck & Aythua fuligula $\mathrm{L}$. & Anatidae \\
\hline White-tailed Sea-eagle & Haliaeetus albicilla $\mathrm{L}$. & Accipitridae \\
\hline Hen Harrier & Circus cyaneus L. & Accipitridae \\
\hline Common Moorhen & Gallinula chloropus L. & Rallidae \\
\hline Yellow Wagtail & Motacilla flava L. & Motacillidae \\
\hline Citrine Wagtail & Motacilla citreola Pallas & Motacillidae \\
\hline Northern Wheatear & Oenanthe oenanthe L. & Muscicapidae \\
\hline \multicolumn{3}{|l|}{ Near Threatened (NT) - 12} \\
\hline Goosander & Mergus merganser L. & Anatidae \\
\hline Red-breasted Merganser & Mergus serrator L. & Anatidae \\
\hline Spotted Crake & Porzana porzana L. & Rallidae \\
\hline Common Ringed Plover & Charadrius hiaticula L. & Charadriidae \\
\hline Common Redshank & Tringa totanus L. & Scolopacidae \\
\hline Common Sandpiper & Actitis hypoleucos $\mathrm{L}$. & Scolopacidae \\
\hline Black-headed Gull & Larus ridibundus L. & Laridae \\
\hline Eurasian Wryneck & Jynx torquilla $\mathrm{L}$. & Picidae \\
\hline Meadow Pipit & Anthus pratensis L. & Motacillidae \\
\hline Wood Warbler & Phylloscopus sibilatrix & Sylviidae \\
\hline
\end{tabular}




\begin{tabular}{|c|c|c|}
\hline & Bechstein & \\
\hline Eurasian Golden Oriole & Oriolus oriolus L. & Oriolidae \\
\hline Common Rosefinch & Carpodacus erythrinus Pallas & Fringillidae \\
\hline
\end{tabular}

In addition to the representative sample of the native Finnish bird compilation, the most striking feature in the bird fauna in the Kokemäenjoki River delta is the rapid establishment of storks, usually considered as southern and more or less exotic birds in the Northern Europe. The Grey Heron (Ardea cinerea L.) established in Finland in 1970's and 1980's, and soon the species became a permanent breeder at the Pihlavanlahti Bay. At present, the number of regularly breeding pairs of the Grey Heron exdeeds one hundred pairs. The other conspicuous southern newcomer is the Great White Egret (Ardea alba L.). This species is now met in the deltaic area annually, ornithologists quite unanimously predict the that the Great White Egret is the next regular breeder in at the Natura area of the Kokemäenjoki River delta.

\subsection{Valuable Waters for Fish and Fisheries}

The Kokemäenjoki River estuary is one of the most popular venues for leisure fisheries in Finland. There are about five thousand leisure fishermen and a few professional fishers in the Pihlavanlahti Bay area and the adjacent archipelago off the estuary. The number of fish species regularly caught here is at least 23 .

In addition to the economic and leisure time values, the Kokemäenjoki River delta is also supports a number of rare and even endangered fish species. The River Kokemäenjoki is one of the sites where the endangered Atlantic salmon (Salmo salar L.; Salmonidae) wanders from the Baltic Sea to spawn, but unfortunately, the dams of hydroelectric power plants prevent the fish from reaching suitable reproduction area upstream. At present, the Baltic Sea stock of the Atlantic salmon is classified as vulnerable (VU) in The 2010 Red List of Finnish Species [31]. Threatening factors are overfishing, construction of waterways (dams preventing breeding migrations), and water pollution.

Of the permanent taxa, the populations of asp (Aspius aspius L. = Leuciscus aspius L.), is classified as Near Threatened (NT), are strong in the estuary. The asp is very popular target species for the leisure fishermen, but the catch of the local stock is probably sustainable.

Eel (Anguilla anguilla L.; Anguillidae) is endangered (EN) both in Finland and globally. Besides fishing and restricted possibilities for migrations between the spawning areas upstream and the sea, a new threat for the eel has emerged in the form of a parasite. The parasite, Anguillacola crassus is nowadays present in different sections of the Kokemäenjoki River watercourse (also in the Pihlavanlahti Bay), but the severity of the threat for the eel is unknown [43].

The European river lamprey (=Lampren) (Lampetra fluviatilis L.; Petromyzontidae) is classified as Near Threatened (NT) in Finland. The River Kokemäenjoki is the most important watercourse in lamprey. The fishing of these fishes from the list of endangered taxa are considered as sustainable. 


\subsection{Nearly Half of the Finnish Dragonfly Taxa Are Present}

The knowledge of the invertebrate fauna of the Kokemäenjoki River delta is unfortunately incomplete - as compared to the amount and coverage of the macrophytic plants and birds. The species composition of dragonflies (Odonata) was thoroughly studied in the estuary by Luoma [44]. A total of 55 species of dragonflies are living in Finland, and of these, 25 species were found in the varying habitats of the Pihlavanlahti Bay area in the 2008 [44].

The diversity of the Odonata fauna - including several taxa rare in Finland - is due to highly varying habitat mosaics, including open wand flowing waters, the availability of the sea, and the wide areas of open meadows bordering the estuary. The most valuable species was the Yellow-spotted Whiteface (Leucorrhinia pectoralis Charpentier; Odonata, Libellulide), an endangered species and also included in the European Union Nature directive appendices II and IV, i.e. destruction of the reproduction and resting locations of the species is strictly forbidden by the EU-wide legislation.

The biota of the Pihlavanlahti Bay - with the adjacent sea shore includes a number of globally, nationally, and regionally endangered species. The best known examples of the rare, conserved and taxa officially classifies as endangered consist of tens of nesting and resting birds. The most recent national evaluation - The 2010 Red List of Finnish Species, compiled by The Environment Ministry and the Finnish Environmental Institute - includes both flora and fauna.

\subsection{Otter Has Always Been Rare, Beaver Is Just Establishing, Muskrat Is Disappearing}

In the fauna of the Kokemäenjoki River delta, the European Otter (Lutra lutra L.) (Carnivora, Mustelidae) is a rare mammalian species classified as endangered in the 2010 Red List of Finnish Species. The conservation category of the otter is Near Threatened (NT). Cause of thereat include trapping/hunting (also non-target), chemical burden by anthropogenic toxic discharges, construction of waterways, traffic and other forms of disturbance. The present occurrence of Lutra lutra in the Pihlavanlahti Bay is uncertain, and the species is not met in all studies and follow-ups in the area.

The European Beaver (Castor fiber L.) has returned to the Kokemäenjoki River delta after decades-long absence and the colonization of the location by the alien North American Beaver (also known as the Canadian Beaver) (Castor canadensis Kuhl.). At present, the European Beaver has several established locations in the western Finland, and the species thrives in the estuary, too. In the 2010 Red List of Finnish Species, C. fiber is classified as vulnerable (VU). Hunting and trapping (also non-target) are the main threatening factors, together with disturbance. The real situation of the European Beaver is nowadays known better than before, and so the category of conservation status is strengthened as compared to the 2000 Red List of Finnish Species.

One of the most striking changes in the biota of the Kokemenjoki River estuary has been the disappearance of the Muskrat (Ondatra zibethicus L.). In the past decades, the muskrat was very common inhabitant throughout the delta, often shaping the landscape by consuming the littoral and aquatic plants. In the 2000's the muskrat has become rare, but the reasons for the disappearance are not known. 


\subsection{Benthic Fauna Is Dominated by Pollution-tolerant Chironomids}

The species composition and abundance of the benthic fauna (invertebtates living at the bottom layer of water bodies) is the most often used biological indicator of the ecological quality of aquatic ecosystems. At the Pihlavanlahti Bay, the severely toxic discharges from the adjacent chemical plant (producing titanium dioxide) destroyed the bottom fauna practically totally in the past decades. But improvements in the water purification and management processes have greatly advanced the status of the environment, both off the coastal waters (Botnian Bay) and at the Pihlavanlahti Bay.

The latest analyses showed that the benthos is gradually revovering, but the living conditions and the status of the bottom fauna are still only tolerable throughout the Pihlavanlahti Bay [45]. The taxa indicating heavy eutrophication and/or anthropogenic pollution dominate the benthos in the estuary. Common species of Chironomidae (Insecta, Diptera) and Oligochaeta, e.g. Limnodrilus spp., L.hoffmeisteri Claparède, Spirosperma ferox Eisen and especially Tubifex tubifex Johannes Muller (the sludge worm) are indisputable signs of anthropogenic pollution.

Of the taxa living usually in pure waters, the clam Unio sp. (Mollusca, Bivalvia) is found as a rare but promising example of the water purification [45]. The recovery of the aquatic fauna is due to the renovation of the waste water management at the local chemical plant, as well as the positive development in the industrial discharges upstream.

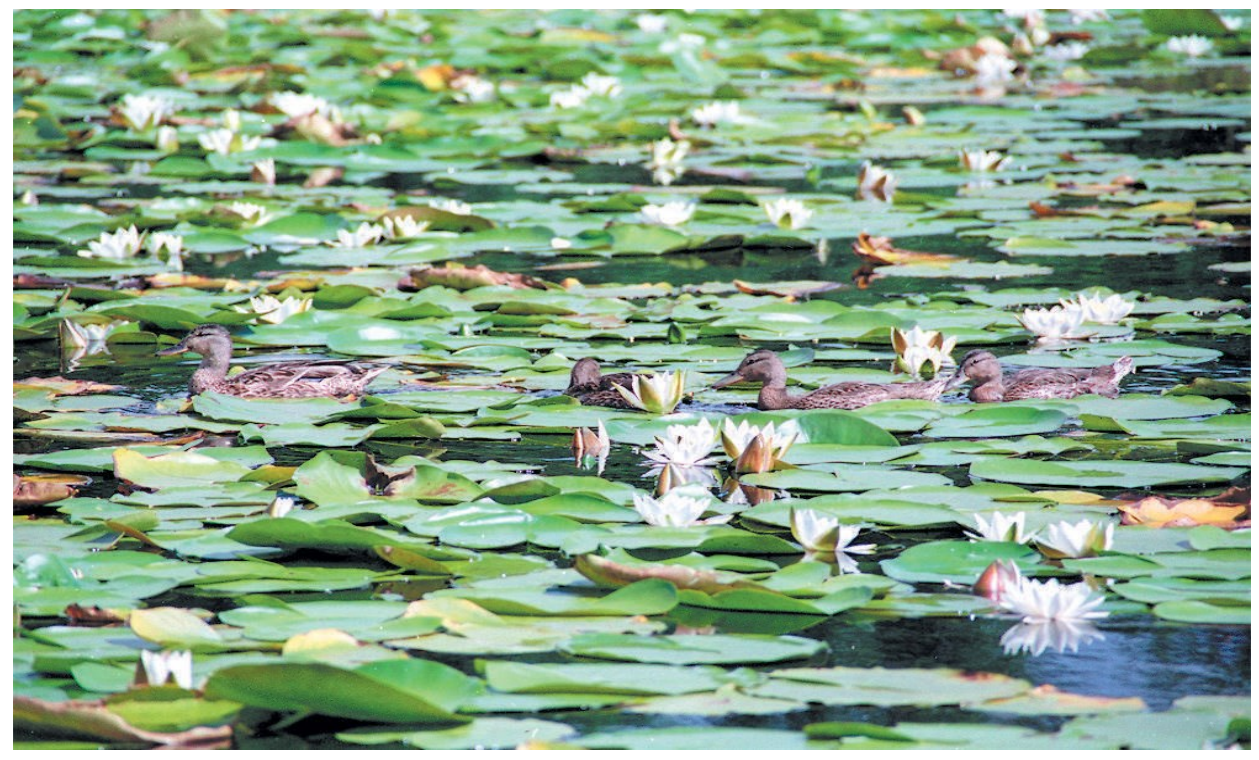

Figure 5. The Kokemäenjoki River delta is a biological treasure, "filled with flora and fauna". The Yellow water-lily (Nymphaea alba) and Mallard (Anas platyrhynchos) are typical inhabitants of the estuary.

\section{THE FUTURE AND MANAGEMENT REQUIREMENTS OF THE DELTA}

The natural conditions in the Kokemänejoki River delta are changing exceptionally rapidly. The continuous progression of the delta and the shallowing of the water depth result in succession of the major vegetation zones and communities, and this in turn affects the fauna occupying the aquatic and littoral habitats. The high biodiversity of the delta is the 
reason for the generous appreciation of the estuary in regional, national and international conservation programmes.

The continuous change is on one hand the positive force for the biodiversity, but on the other hand, the change also can destroy the characteristics, on which the biological values are based. As a consequence, the delta has to be carefully managed to preserve the values of the natural environment. Variations in the biotic and abiotic environmental conditions especially in the area for the Natura 2000 - have to be surveyed continuously.

One of the most conspicuous threats for the natural values of the delta are the dredging operations, already widely fulfilled and to be accomplished in the future [2],[21]. Management is necessary for the flood prevention - plans and managements are already going on, and such operations are necessarily to be extended in the future - as well as the local dredging required to keep the channels navigable.

And finally - to emphasize the values presented here - the deltas of the world are amongst the most vulnerable habitats in the wake of the water level rise and enhanching floods and storms, to be experienced due to the climatic change [46].

\section{References}

[1] Southeast Finland ELY Centre. The Kokemäenjoki Estuary. (2014). http://www.environment.fi/enUS/KokemaenjokiLIFE_2006_2012/Project_areas/The_Kokemaenjoki_Estuary

[2] Varsinais-Suomen ELY-keskus. Kokemäenjoen suisto. (2013). ttp://www.ymparisto.fi/fiFI/Luonto/Suojelualueet/Natura_2000_alueet/Kokemaenjoen_suisto (5327)

[3] Aulio K. Publicationes Instituti Geographici Universitatis Turkuensis (1979) 90 1-30.

[4] Aulio K. Research Journal of Biology (2014) 2 7-16.

[5] Kotilainen H, Lehtoranta R, Häkkilä K and Virtanen M. Vesi- ja ympäristöhallituksen monistesarja (1988) 112 1-63 + 39 Appendices.

[6] Cripps C, Peltonen J, Räsänen M, Huhta P and Niinikoski J. Centre for Economic Development, Transport and the Environment for Southwest Finland, Publications (2011) 13/2011 1-61.

[7] Säntti AA. Publicationes Instituti Geographici Universitatis Turkuensis (1954) 29 1-61.

[8] Johansson MM, Kahma KK, Boman H and Launiainen J. Boreal Environment Research (2004) 9(2) 153-166.

[9] Aulio K. Baltic Cities Environmental Bulletin (2010) 2/2010 7.

[10] Lisitzin, E. Merentutkimuslaitoksen Julkaisu (1952) 153 1-20.

[11] Westerling H. Ympäristö ja Terveys (1973) 4 318-323.

[12] Isotalo I. Publications of the Water Research Institute (1979) 30 3-20.

[13] Bagge P and Lehmusluoto P. Merentutkimuslaitoksen Julkaisuja (1971) 235 3-18.

[14] Perälä H. Kokemäenjoen vesistön vesiensuojeluyhdistys ry, Julkaisu (2012) 644 1-67 + Appendices. 
[15] Putkuri E, Lindholm M and Peltonen A. State of the environment in Finland 2013. SYKE Publications (2013) 1 1-112.

[16] Häkkilä K. Vesi- ja ympäistöhallituksen monistesarja (1987) 53 1-48.

[17] Venho J. Ilmatieteellisen keskuslaitoksen julkaisuja (1963) 3.

[18] Sarkkula J and Virtanen M. Nordic Hydrology (1978) 9 43-56.

[19] Atlas of Finland 1990. Geology, Folio 123-126 (Alalammi P. (Ed.). (1990) National Board of Survey and Geographical Society of Finland.

[20] Mansikkaniemi H. Fennia (1975) 143 1-38.

[21] Lievonen T. Kokemäenjoki LIFE (LIFE06/NAT/FIN/000129). (2011) Centre for Economic Development, Transport and the Environment.

[22] Häyrén E. Acta Sociatatis pro Fauna et Flora Fennica (1909) 32 1-266.

[23] Ihantola R. Memoranda Societatis pro Fauna et Flora Fennica (1980) 56 1-5.

[24] Ihantola R. Porin kaupungin julkaisuja (1981) 40 1-20 + 26 Appendices.

[25] Kalinainen P. 1983. Porin kaupungin tutkimuksia (1983) 51/1983.

[26] Lampolahti J. Porin ympäristönsuojelulautakunnan julkaisu (1989) 2/89 2-41 + 17 Appendices.

[27] Lampolahti J. Luonnon Tutkija (1991) 95(1-2) 11-14.

[28] Paakkinen M. Kokemäenjoen vesistön vesiensuojeluyhdistys ry, Julkaisu (2002) 4461 $16+$ Appendices.

[29] Ahlman S. Porin Kokemäenjoen suiston ja Kolpanlahden kasvillisuusselvitys 2008. [Study on the vegetation of the Kokemäenjoki River estuary and the Kolpanlahti Bay, Pori, 2008. In Finnish], (2008). 134 pp. The Ahlman Group Oy.

[30] Suominen J. Norrlinia (2013) 26 1-783.

[31] Rassi P, Hyvärinen E, Juslén A \& Mannerkoski I (Eds.) The 2010 Red List of Finnish Species. Ministry of the Environment \& Finnish Environment Institute. (2010). Helsinki. $685 \mathrm{pp}$. The publication is also available in the Internet: www.environment.fi/redlist

[32] Säntti AA. Acta Geographica (1954) 14 359-378.

[33] Aulio K. Research Journal of Biology (2014) 2 53-59, 2014.

[34] Aulio K. Journal of Plant Sciences (2014) 2(4) 120-128.

[35] Aulio K. International Letters of Natural Sciences (2015) 1(2015) 34-46.

[36] Aulio K. Luonnon Tutkija (1981) 85: 61.

[37] Aulio K. Publications of the Water Research Institute, National Board of Waters and Environment, Finland (1986) 68 171-174.

[38] Aulio K and Salin M. Bulletin of Environmental Contamination and Toxicology (1982) 29(3) 320-325.

[39] BirdLife International. Important Bird Areas factsheet: Pori archipelago and wetlands. (2014). Downloaded from http://www.birdlife.org on 04/12/2014. 
[40] Asanti T, Gustafsson E, Hongell H, Hottola P, Mikkola-Roos M, Osara M, Ylimaunu J and Yrjölä R. The Finnish Environment (2005) 596en 1-58.

[41] Lampolahti J. Kokemäenjoen suiston linnusto [The Avifauna of the Kokemäenjoki River delta. In Finnish]. In: Soikkeli M (Ed.) Satakunnan linnusto. (1984). Porin Lintutieteellinen Yhdistys, pp. 17-45.

[42] Alho P. Kokemäenjoen suiston linnustoselvitys 2008 [Study on the Avifauna of the Kokemäenjoki River delta 2008. In Finnish]. Lounais-Suomen ympäristökeskuksen raportteja (2009) 10/2009 1-94.

[43] Tukonen J. Kokemäenjoen ankeriastutkimus [Study on the lampreys in the Kokemäenjoki River. In Finnish]. (2013). Evon riistan- ja kalantutkimus.

[44] Luoma S. Kokemäenjoen suiston sudenkorentoselvitys 2008. [The Dragonfly fauna of the Kokemäenjoki River delta in 2008. In Finnish]. Lounais-Suomen ympäristökeskuksen raportteja (2009) 4/2009 1-51.

[45] Valkama J. Kokemäenjoen vesistön vesiensuojeluyhdistys ry, Julkaisu (2014) 704 1-43.

[46] Giosan L, Syvitski J, Constantinescu S and Day J. Nature (2014) 516(7529) 31-33. 